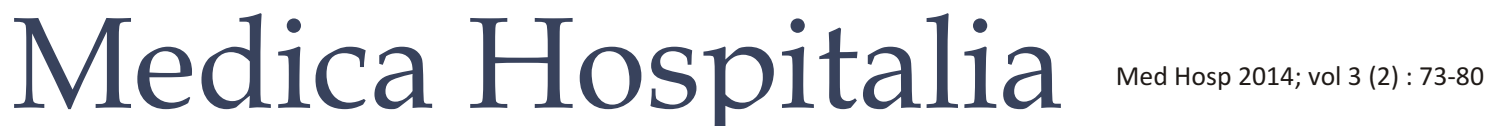

Review Article

\section{Peran Aromatase Inhibitor pada Pasien Resisten Clomiphene Citrate}

\author{
Noor Pramono \\ Departemen Obstetri dan Ginekologi, Divisi Endokrinologi Reproduksi, \\ Fakultas Kedokteran Universitas Diponegoro / RSUP. Dr. Kariadi Semarang
}

\begin{abstract}
Abstrak
Latar belakang : Penyebab anovulasi oleh WHO diklasifikasikan menjadi 3 kategori berdasar tempat lesinya. WHO tipe 2 (normogonadotropic hypogonadism), paling banyak menjadi penyebab anovulasi, dan paling sering oleh karena PCOS. Induksi ovulasi yang digunakan adalah clomiphene citrate, sebagai lini pertama terapi; dan bila resisten, gagal, dilanjutkan dengan terapi alternatif. Resisten clomiphene citrate (resisten-CC) adalah pasien yang gagal berovulasi setelah menerima $150 \mathrm{mg} /$ hari atau $200 \mathrm{mg} /$ hari selama 5 hari, atau tetap anovulasi setelah terapi CC standar (100 mg perhari untuk 5 hari selama 2-3 siklus). Terapi alternatif untuk pasien resisten-CC banyak cara, di antaranya adalah aromatase inhibitor (Al). Review ini bertujuan untuk mempelajari farmakologi, cara kerja, cara pemberian, keberhasilan, dan efek samping Al.

Metode : Telaah pustaka

Hasil : Generasi ke-3 Al adalah Exemestane, Letrozole (L), dan Anastrozole $(A)$, untuk terapi kanker payudara. $L$ dan $A$ dikenal untuk induksi ovulasi. Induksi ovulasi dengan A $1 \mathrm{mg} /$ hari atau $\mathrm{L}$ $2.5 \mathrm{mg} /$ hari selama 5 hari mempunyai keberhasilan yang sama. Pemberian L pada hari ke 3-7 menstruasi, menghambat aromatase di ovarium,terjadi akumulasi androgen intraovarium, sekresi E2 ovarium tertekan akan mengurangi umpan balik negatif-estrogen pada hipothalamus dan pituitari. Terjadi peningkatan sekresi FSH dari pituitari anterior. Akumulasi androgen di dalam folikel akan meningkatkan sensitivitas folikuler terhadap FSH, folikulo genesis yang terjadi menghasilkan folikel multipel. Akhir fase folikuler, pengaruh Al menurun, dan kadar E2 meningkat, terjadi pertumbuhan folikel. Oleh karena Al tidak mempengaruhi pusat reseptor esterogen, kadar E2 yang meningkat berakibat umpan balik negatif normal pada sekresi FSH, folikel yang lebih kecil dari folikel dominan mengalami atresi, dengan hasil ovulasi monofolikuler. L tidak mempunyai efek samping anti estrogenik perifer, dan half-life 48 jam, obat hilang dari tubuh 10 hari setelah obat terakhir, sehingga jarang terjadi simtom antiestrogenik. Efek samping utama adalah hotflash, nyeri otot ringan, dan keluhan gastrointestinal. Terapi A dan L tidak didapati OHSS maupun kehamilan multipel. Tidak mempunyai pengaruh negatif terhadap endometrium maupun mukus serviks. Angka kehamilan dan angka kelahiran hidup cukup tinggi. Dengan
\end{abstract}

\section{Role of aromatase inhibitor in CC-resistent patient}

\begin{abstract}
Background : Causes of anovulation have been classified by the WHO into 3 categories based on the site of the lesion. WHO type 2 (normogonadotropic hypogonadism) is the commonest cause of ovulation, and is most commonly caused by polycystic ovarian syndrome. Ovulation can be induced by clomiphene citrate (CC), as the first line treatment, if resistence or failed, continued by an alternative treatment. Clomiphene citrate resistance, which refers to persistence of anovulation after accepting $150 \mathrm{mg}$ or $200 \mathrm{mg}$ per-day for 5 days or standard CC treatment ( $100 \mathrm{mg}$ per-day for 5 days during 2-3 cycles), occurs in $15-20 \%$ of patients. Many kinds of alternative treatment, one of them is aromatase inhibitor (AI). The objectives of this review was to study the pharmacology, mode of action, treatment regimens, success rate and side effects of aromatase inhibitor.

Methods : Literature review

Results : The third generation of Als are exemestane, letrozole, anastrozole, have been approved to treat advanced breast carcinoma. Letrozole and anastrozole have succed for induction ovulation. Letrozole $2.5 \mathrm{mg} /$ day and anastrozole/day have the same outcomes. Administration Al from days 3 to 7 suppresses ovarian E2 secretion and reduces estrogen-negative feedback at the pituitary and mediobasal hypothalamus. Increased FSH secretion from the anterior pituitary stimulates growth of multiple ovarian follicles. Later in the follicular phase, the effect of the Al is reduced, and E2 levels increase as a result of follicular growth. Because Al do not affect estrogen receptors centrally, the increased E2 levels result in normal negative feedback on FSH secretion and follicles smaller than the dominant follicle undergo atresia, with resultant monofollicular ovulation. Letrozole do not have the peripheral antiestrogenic effects. The half-life of letrozole is $45-48$ hours, resulting in complete clearance in 10 days after taking the last tablet, thus the antiestrogenic symptoms is rare. The main side effects are hotflash, mild muscle pain, and gastrointestinal disturbances. Aromatase inhibitor do not have the incidence of OHSS or multiple pregnancy, do not have negative
\end{abstract}


L didapatkan untuk angka ovulasi $70-85 \%$, kehamilan $20-27 \%$, tidak menunjukkan adanya peningkatan risiko anomali fetal atau keluaran kehamilan yang merugikan. Angka kehamilan dan kelahiran hidup lebih tinggi daripada CC. Hasil meta-analisis menunjukkan bahwa L lebih unggul dari CC untuk terapi PCOS yang belum pernah menggunakan induksi ovulasi sebelumnya atau resisten-CC. Tidak ada beda efektivitas dengan laparoskopi drilling ovarium.

Simpulan : Salah satu terapi alternatifpasien resisten-CC adalah dengan $L$ 2,5 mg atau $A 1$ mg perhari pada hari ke 3-7 menstruasi. L dan A tidak berpengaruh negatif pada endometrium maupun mukus serviks, angka ovulasi $70-85 \%$, kehamilan $20-27 \%$, kelahiran hidup cukup tinggi, tidak meningkatan risiko anomali fetal, tidak didapatkan OHSS maupun kehamilan multipel.

Kata kunci : Clomiphene citrate, aromatase inhibitor, anastrozole, letrozole. effect to endometrium or cervics mucus. The use of letrozole, ovulation rate $70-85 \%$, pregnancy rate $20-27 \%$, do not show increasing risk of fetal anomaly or harm pregnancy outcome. Pregnancy and live birth rate are higher than CC treatment. Study meta-analysisfindings suggest that letrozole is superior to $\mathrm{CC}$ for the treatment of subfertility in women with PCOS who have had no previous treatment for ovulation induction or are resistent to CC. There is no difference in effectiveness between letrozole and laparoscopic ovarian drilling.

Conclusion : One of the alternative treatment for CC-resistent is letrozole $2.5 \mathrm{mg}$ or anastrozole $1 \mathrm{mg}$ per day for 5 days starting from day 3 of the menses. The half-life of letrozole is 48 hours, complete clearance in 10 days after taking the last tablet. Letrozole does not have negatif effect on endometrium nor cervix mucus, ovulation rate $70-85 \%$, pregnancy rate $20-27 \%$, live birth rate is high, no increased risk of fetal anomaly. Treatment with anastrozole or letrozole does not show OHSS nor multiple pregnancy.

Keywords : Clomiphene citrate, aromatase inhibitor, anastrozole, letrozole

\section{PENDAHULUAN}

Infertilitas oleh karena anovulasi adalah masalah yang paling sering dihadapi oleh klinik infertilitas. Anovulasi merupakan masalah yang berkaitan dengan ovarium, pituitari atau hipothalamus. Penyebab anovulasi oleh WHO diklasifikasikan menjadi 3 kategori utama berdasar tempat lesinya, refleksinya merupakan tampilan gonadotropin. WHO tipe 1 (hypogonadotropic hypogonadism), dapat disebabkan lesi pada pituitari atau hipothalamus dan mempengaruhi produksi gonadotropin; WHO tipe 2 (normogonadotropic hypogonadism), yang paling banyak menjadi penyebab anovulasi dan paling sering oleh karena PCOS; WHO tipe 3 (hypergonadotropic hypogonadism, umumnya merupakan kegagalan ovarium. Induksi ovulasi dapat dilakukan pada WHO tipe 1 dan 2. Pada WHO tipe 3, induksi ovulasi umumnya tak berhasil oleh karena kehabisan/ penipisan folikel, untuk dapat hamil hanya dengan donasi oosit. WHO tipe 1, terapi menggunakan kombinasi FSH danLH; WHO tipe 2, yang paling sering adalah PCOS, induksi ovulasinya menggunakan anti estrogen seperti clomiphene citrate (CC) sebagai lini pertama terapi, dan bila gagal dilanjutkan dengan terapi alternatif. ${ }^{1}$

CC adalah anti estrogen, Selective Estrogen Receptor Modulator (SERM), merupakan terapi farmakologi lini pertama untuk induksi ovulasi perempuan infertilitas anovulasi (WHO tipe 2), telah dipakai lebih dari 40-45 tahun. Mempunyai pengaruh positif pada ovarium berupa keberhasilan ovulasi, dan pengaruh negatif berupa penipisan endometrium dan endoserviks. ${ }^{1-4} \mathrm{CC}$ mengikat reseptor estrogen (RE) di hipothalamus, dan akibat dari umpan balik negatif estrogen, akan meningkatkan produksi FSH, yg berpengaruh pada perkembangan folikel. Dosis $50-150 \mathrm{mg} /$ hari selama 5 hari mulai hari ke-2-6 menstruasi. ${ }^{1-4}$

Efek samping utama, pengaruh negatif, adalah berhubungan dengan pengaruh anti estrogen, sentral adalah hotflash sedangkan perifer adalah penipisan endometrium dan endoserviksehingga angka kehamilan rendahyang tidak sesuai dengan angka keberhasilan ovulasi yang tinggi ${ }^{1-4}$ efek samping yang jarang tetapi serius adalah simtom visual ovarium seperti pandangan kabur, diplopia, dan fotosensitif. Sedangkan potensi multifolikuler akan memberikan kesempatan $8 \%$ untuk kehamilan multipel. Efek samping yang sangat jarang adalah OHSS. ${ }^{1}$

Pasien resisten-CC adalah pasien yang gagal berovulasi setelah menerima $150 \mathrm{mg} / \mathrm{hari}^{1,2}$ ada yang memakai batasan $200 \mathrm{mg} /$ hari5, atau dengan batasan tetap anovulasi setelah terapi CC standar (dosis $100 \mathrm{mg}$ perhari untuk 5 hari selamaa 2-3 siklus). ${ }^{6}$ Angka kejadian resisten-CC adalah $15-20 \%{ }^{4,6}$ Terapi alternatif untuk pasien resisten-CC banyak cara, di antaranya adalah memperpanjang lama pemberian CC, diganti dengan aromatase inhibitor (AI), tamoxifen, gonadotropins, ovarian drilling, dan invitro fertilization (IVF) ${ }^{7}$

Aromatase inhibitor untukterapi neoplasma sex steroid dependent, dengan cara menekan produksi estrogen di dalamnya. AI dipakai pertama kali untuk terapi kanker payudara, dengan nama Aminoglutethimide yang merupakan generasi pertama, dilanjutkan dengan generasi kedua yang mempunyai efek aromatase lebih spesifik dan kurang toksik, dengan nama Fadrozole dan Formestane. Dan pada tahun 1996, 
AI generasi ke tiga adalah Exemestane, Letrozole (L), dan Anastrozole (A), telah disetujui oleh United States Food and Drug Administration (US FDA). Anastrozole (Arimidex; AstraZeneca), Letrozole (Femara; Novartis), Exemestane (Aromasin; Pfizer) telah disetujui untuk terapi kanker payudara stadium lanjut perempuan post menopause. ${ }^{4,8}$ Efek sampingnya ringan, nyeri kepala ringan, mual, diare; hotflash ringan dan jarang, pengaruh pada profil lipid masih perlu klarifikasi, penggunakan jangka panjang potensi untuk osteoporosis dan osteopenia. ${ }^{8}$ Sekarang AI dikembangkan untuk terapi endometriosis yang gagal dengan terapi medik dan operatif untuk memperbaiki nyeri dan lainnya, yang ditujukan pada molekul aromatase didalam endometriosis. A dan $\mathrm{L}$ telah berhasil dipergunakan untuk mengobati endometriosis. ${ }^{8}$ Anastrozole dan letrozole terbukti juga bermanfaat untuk induksi ovulasi. Lini pertama induksi ovulasi tetap menggunakan CC, sedangkan lini kedua-ketiga adalah AI, AI tidak dapat sebagai pengganti CC, kecuali pada pasien yang resistenCC. ${ }^{3,9}$ L akhir-akhir ini dikenal oleh karena keberhasilannya untuk induksi ovulasi dan IVF walaupum tanpa label dari pabrik pembuatnya. ${ }^{10} \mathrm{~L}$ tidak mempunyai efek samping anti estrogenik perifer dan mempunyai half-life 45-48 jam, sehingga jarang terjadi simtom antiestrogenik. Efek samping utama adalah hotflash, nyeri otot ringan, dan keluhan gastrointestinal hampir $1 \%{ }^{10,11}$

\section{Clomiphene Citrate}

Farmakologi : CC adalah suatu derivat nonsteroidal triphenylethylene yang menunjukkan khasiat kedua agonis dan antagonis estrogenik. Agonis estrogenik berhasil apabila kadar estrogen endogen menjadi sangat rendah. Artinya, CC bekerja sebagai suatu kompetitor antagonis estrogen. CC dibersihkan melalui liver dan diekskresi dalam tinja (stool). Hampir 85\% dari dosis yg diberikan lenyap setelah 6 hari, walaupun sisanya dapat tinggal dalam sirkulasi untuk saat yang lebih lama. Saat ini pabrik membuat CC dengan komposisi campuran 2 isomer geometrik enclomiphene dan zuclomiphene dengan perbandingan $3: 2 .^{7}$

Cara kerja : Stukturnya mirip estrogen (E) sehingga CC dapat mengikat reseptor estrogen (RE) pada sistem reproduksi. Walaupun demikian, bertentangan dengan estrogen, CC mengikat inti RE untuk suatu periode waktu yang lama dan berakibat menipisnya konsentrasi RE (dengan cara mempengaruhi proses normal pengisian/penambahan kembali RE). Kemanjuran obat pada induksi ovulasi dapat dilihat dari pengaruhnya ditingkat hipotalamik. Menipisnya RE hipotalamik menyebabkan tingkat sirkulasiestrogen menurun. Penurunan kadar estrogen berumpan balik memicu mekanisme kompensasi normal yang mengubah sekresi pulsatil gonadotropin-releasing hormone (GnRH) hipotalamik menjadi stimulasi meningkatnya pelepasan gonadotropin pituitari yang berakibat pengendalian aktivitas folikuler ovarium. Pada perempuan berovulasi, terapi CC meningkatkan frekwensi denyut GnRH. Pada perempuan anovulasi dengan polycystic ovary syndrome (PCOS) dimana frekwensi denyut GnRH sudah abnormal tinggi, terapi CC akan meningkatkan amplutido denyut, tetapi tidak frekwensinya. Selama terapi CC, kadar LH dan FSH meningkat, dan turun kembali setelah serangkaian 5 hari terapi selesai dikerjakan. Pada siklus terapi yang berhasil, satu atau lebih folikel dominan muncul dan matang. Paling sering, LH surge terjadi pada 5-12 hari setelah dosis terakhir CC.

Pemberian CC pada hari ke 3-7 mensis, terjadi penipisan RE pada tingkat hipothalamus mediobasal dan pituitari, Sehingga umpan balik negatif-estrogen kesentral diganggu, berakibat sekresi FSH dari pituitari anterior meningkat, menyebabkan pertumbuhan folikel multipel. Pada akhir fase folikuler, dikarenakan retensi jaringan yang lama dari CC, penipisan RE berlanjut secara sentral dan peningkatan sekresai E2 dari ovarium tidak mampu memberikan umpan balik negatif normal pada FSH. Sebagai akibatnya terjadi pertumbuhan folikel dominan multipel dan ovulasi multipel. ${ }^{12}$

CC mempengaruhi umpan balik negatif $\mathrm{E}$ pada poros hipotalamus-pituitari, terjadi lebih dari 50\% peningkatan FSH dan LH endogen. ${ }^{13}$ Gonadotropin yang meningkat tersebut berakibat angka ovulasi menjadi $60-85 \%$, angka kehamilan kumulatif $30-40 \%$, pada siklus $3-6 .^{13}$ Ada yang mendapatkan angka ovulasi, kehamilan dan lahir hidup berturut-turut adalah $49 \%, 30 \%$, dan $23 \%$; rendahnya angka tersebut selain oleh karena penipisan endometrium juga oleh karena meningkatnya sekresi LH yang dapat menyebabkan leutinisasi prematur dari folikel yang berkembang. ${ }^{1}$

\section{Regimen terapi standar:}

CC diberikan secara oral untuk 5 hari, dimulai pada hari ke 2-6 menstruasi spontan atau induksi-progestin. Walaupun terapi dimulai pada hari ke-2, 3, 4, atau 5, akan tetapi hasil ovulasi, konsepsi, dan kehamilan adalah serupa. Dosis $50 \mathrm{mg}$ perhari untuk 5 hari, dinaikkan 50 mg tiap siklus berikutnya sampai menghasilkan siklus berovulasi. Standar dosis efektif 50-250 mg perhari, akan tetapi dosis melebihi $100 \mathrm{mg}$ perhari, tidak disetujui oleh US FDA. Kehamilan umumnya akan terjadi pada 3-6 bulan pertama pemberian. Pemberian melebihi 6 siklus tidak dianjurkan, dan perlu diingat kemungkinan dosis resisten. ${ }^{7}$

\section{Regimen terapi alternatif :}

Pada perempuan yang gagal dengan regimen terapi standar, beberapa protokol CC alternatif muncul, ada penelitian yang masih terbatas menganjurkan pemberiannya diperpanjang menjadi 7-8 hari. Bagi mereka yang gagal merespon suatu pemberian dosis CC, 
progestin diberikan untuk menginduksi menstruasi yang kemudian dilanjutkan dengan pemberian dosis CC yang lebih tinggi. Akhir-akhir ini protokol stair-step dianjurkan, dimana sekali gagal berovulasi dengan menggunakan suatu pemberian dosis yang dapat dikenali pada hari ke 14-21, maka dosis CC yang lebih tinggidapat diberikan segera tanpa dimulai induksi perdarahan withdrawal dengan progestin. Induksi perdarahan menstruasi dengan progestin sebelum pemberian CC pada perempuan anovulasi berhubungan dengan rendahnya angka konsepsi dan kelahiran hidup. ${ }^{7}$ Alternatif lain adalah AI, tamoxifen, gonadotropin, ovarian drilling, IVF. ${ }^{7}$

\section{Regimen terapi tambahan:}

Perempuan yang terbukti resisten atau tak mempan dengan terapi standar CC mungkin dapat berovulasi dengan regimen terapi kombinasi. Kombinasi ini tergantung keadaan pasien tersebut perlukah tindakan yang lebih agresif, misalnya pemberian gonadotropin eksogen, dan atau IVF dan masih banyak faktor lainnya, misalnya umur, tujuan, toleransi risiko. ${ }^{7}$ Induksi ovulasi dengan CC misalnya pada pasien dengan PCOS, sebelumnya dapat diberikan metformin dengan dosis 1500-1700mg perhari dengan hasil ovulasi dan kehamilan yang memuaskan. ${ }^{7}$ Terapi tambahan lain dengan glukokortikoid. Terapi CC ditambah dexamethason $0.5 \mathrm{mg}$ perhari pada hari ke 5-9 mensis, hasilnya lebih baik dibanding yang tidak ditambah dexamethason (dari 23 pasien yang berovulasi 23 dan yang berhasil hamil 17), dan 2 penelitian yang luas lain, dimana pemberian dexamethason pada siklus hari ke 3-12 pada terapi CC, didapatkan $75-88 \%$ berovulasi dan $40 \%$ kehamilan, sedangkan yang hanya CC lebih rendah.7Ada yang memberikan terapi tambahan $\mathrm{N}$-acetyl cysteine (NAC) pada PCOS yang diberikan CC. ${ }^{6}$

Refaeey AE dkk, meneliti 110 perempuan (153 siklus) PCOS yang resisten-CC (150 mg/hari untuk 5 hari selama 2-3 siklus tetap anovulasi atau ovulasi dengan endometrium sangat tipis, $<5 \mathrm{~mm}$, (pada hari pemberian HCG). Kelompok I (55 pasien) mendapatkan CC $150 \mathrm{mg} /$ hari pada hari ke 2-6 menstruasi ditambah CoQ10 60 mg 3 kali sehari di mulai hari ke 2 menstruasi sampai pada hari pemberian HCG. Pada kelompok II (55 pasien) hanya CC dengan cara yang sama. Hasilnya dengan kombinasi tersebut lebih efektif, murah, aman untuk stimulasi perkembangan folikel sebelum tindakan pemberian gonadotropin dan laparoskopi drilling ovarium. ${ }^{14}$ Terapi tambahan dengan gonadotropin, misalnya hMG dan atau FSH. Selain mahal juga diperlukan klinikus yang terlatih dan berpengalaman.7

\section{Aromatase Inhibitor}

Anastrozole (A) dan letrozole (L)adalah AI yang akhirakhir ini sering digunakan untuk induksi ovulasi. AI maupun obat-obatan umumnya, akan bersih sempurna pada kurang lebih 5 half-life, dan konsentrasinya berada dibawah kadar terapeutik pada 3-4 half-life. Half-life L kurang-lebih 48 jam, sehingga bersih menyeluruh kurang lebih 10 hari setelah obat terakhir, dan konsentrasi dibawah kadar terapeutik pada 6-8 hari. ${ }^{6,12}$ Penelitian Badawy dkk., 2008, anastrozole dan letrozole memberikan hasil yang serupa. Tidak didapatkan kejadian ovarian hyperstimulation syndrome (OHSS) maupun kehamilan multipel. ${ }^{6,9}$ Letrozole adalah AI berpotensi tinggi, selektif, kompetitif, pengaruhnya reversibel, tidak mempunyai pengaruh negatif terhadap endometrium maupun mukus serviks. ${ }^{5,6}$

Pemberian L pada hari ke 3-7 mensis akan menghambat aromatase di ovarium, sehingga androgen intraovarium terjadi akumulasi, melimpah, sekresi E2 ovarium tertekan dan akan mengurangi umpan balik negatif-estrogen pada hipothalamus mediobasal dan pituitari. Terjadi peningkatan sekresi FSH dari pituitari anterior, dan akumulasi androgen didalam folikel akan meningkatkan sensitivitas folikuler terhadap $\mathrm{FSH}^{2}$ Akumulasi androgen akan menstimulasi insulin-like growth factor I (IGF-I), bersama dengan faktor endokrin dan parakrin lain, akan bersinergis dengan FSH sehingga terjadi folikulogenesis, ${ }^{6}$ terjadi pertumbuhan folikel ovarium multipel. Akhir fase folikuler, pengaruh AI menurun, dan kadar E2 meningkat sebagai akibat pertumbuhan folikel. Oleh karena AI tidak berpengaruh pada pusat RE, kadar E2 yang meningkat berakibat umpan balik negatif normal pada sekresi FSH dan kemudian folikel yang lebih kecil dari folikel dominan mengalami atresi, dengan hasil ovulasi monofolikuler pada sebagian besar kasus. ${ }^{2,6,11,12}$

Kucherov A dkk, 2011, meneliti 5 perempuan normal diberi L 2,5 mg perhari untuk 7 hari, mulai hari pertama menstruasi, didapatkan rata-rata $\mathrm{LH}$ dan amplutido denyut LH meningkat, tetapi tidak frekwensi denyut LH, menunjukkan bahwa L juga bekerja pada hipofisis (pituitari). Sedangkan CC bekerja pada hipotalamus dan hipofisis oleh karena frekwensi dan amplutido denyut FSH dan LH meningkat. ${ }^{13}$

Untuk induksi, L sama dengan CC, dalam hal rekrutmen folikel maupun angka ovulasi. L tidak sama dengan CC, AI tidak meng-antagonis RE di endometrium, sehingga angka kehamilan dan angka kelahiran hidup lebih tinggi. ${ }^{15}$ Sebagian besar penelitian mengevaluasi pengaruh AI pada perkembangan endometrium yang berfokus pada parameter morfologi. Ketebalan endometrium tengah-siklus, morfologi dan pembentukan pinopode setelah pemberian $\mathrm{L}$ menunjukkan keadaan yang sebanding dengan karakteristik morfologi dari siklus natural. ${ }^{6,15}$ Walaupun demikian perlu dicatat dan dipertanyakan mengenai korelasi positif dari ekspresi pinopode dan reseptivitas endometrium. Data mengenai fungsi endometrium dalam siklus L masih kurang. ${ }^{15}$ Montville CP, 2010, L 
mempengaruhi fungsi dan perkembangan endometrium. L secara konsisten berhubungan dengan reduksi konsentrasi serum E2 fase folikuler jika dibanding dengan siklus natural maupun siklus CC. Kadar E2 pada saat ovulasi bervariasi. Serum E2 menurun atau sama dengan kadar siklus natural. Jika dibandingkan dengan siklus CC, ke dua kadar E2 preovulatori dan folikel matur adalah lebih rendah pada siklus L. Hal ini perlu dibuktikan apakah reduksi konsentrasi E2 fase folikuler mempunyai efek jelek pada perkembangan endometrium. ${ }^{15}$ Oleh karenanya penelitian disini membuktikan bahwa luteal suport dengan progesteron intravagina meningkatkan angka kehamilan klinik pada perempuan PCOS dengan L untuk induksi ovulasi. ${ }^{15}$ Casper dan Mitwally mempunyai hipotesis bahwa reduksi konsentrasi E2 fase folikuler akan berakibat pada up-regulation dari ekspresi RE di endometrium. Disebabkan karena AI mempunyai half-life pendek, up-regulation dari reseptor akan menghasilkan suatu respon cepat meningkatkan kadar E2, berakibat seperti perkembangan endometrium normal. ${ }^{4,15}$

Dosis pemakaian Lpada PCOS yang resisten terhadap CC adalah 2,5 mg per hari pada hari ke 3-7 mensis, ${ }^{2}$ yang sepadan dengan dosis A $1 \mathrm{mg}$ perhari. ${ }^{6}$ Keberhasilan L untuk induksi ovulasi telah lama menarik perhatian, dengan angka ovulasi $70-85 \%$, kehamilan 20-27\% tiap siklus. Sedangkan pada PCOS resisten-CC, angka ovulasi $54,6-84,4 \% .^{2}$ Casper dan Mitwally menggunakan dosis L 2,5 mg perhari mendapatkan angka ovulasi $75 \%$ dan kehamilan 25\%. ${ }^{6}$ L dapat menginduksi ovulasi dengan cara menurunkan kadar E untuk sementara, menginduksi peningkatan FSH. L tidak mengikat ER sehingga tak mempunyai efek langsung pada endometrium. ${ }^{3}$ Sedangkan penelitian yang dilakukan pada 36 perempuan PCOS yang resisten-CC diberikan terapi L 2,5 mg perhari mulai hari ke 2-6 menstruasi, angka ovulasinya 33,3\%. ${ }^{5}$ Mirip dengan CC, AI juga peroral untuk waktu yang singkat, tidak terlalu mahal, dan sedikit efek samping. ${ }^{13}$ Kemanjuran secara keseluruhan dari L tampak sebanding dengan atau lebih baik dari CC dan tamoxifen. Hal ini sehubungan dengan berkurangnya perkembangan folikel yang multipel, dan hal ini akan mengurangi angka kejadian kehamilan multipel di banding $\mathrm{CC}$. $^{13}$

Pada penelitian 90 perempuan infertilitas yang diberi L- inseminasi intrauterin, dibandingkan antara BMI $<30 \mathrm{~kg} / \mathrm{m}^{2}$ dan BMI $\geq 30 \mathrm{~kg} / \mathrm{m}^{2}$, BMI yang lebih tinggi condong angka kehamilannya lebih tinggi daripada BMI yang lebih rendah. ${ }^{16}$

Akhir-akhir ini, L diusulkan sebagai obat infertilitas paling efektif dan dapat digunakan untuk induksi ovulasi pada PCOS. ${ }^{17}$ Obat ini direkomendasikan menjadi obat pengganti untuk CC sebagai terapi lini pertama untuk induksi ovulasi pada PCOS, L juga dipertimbangkan sebagai suatu alternatif dari CC pada perempuan infertil ovulasi maupun anovulasi. Obat ini dapat dapat menginduksi ovulasi $62 \%$ dari pasien yang resisten-CC, dengan angka kehamilan 14,7\%. L direkomendasikan untuk pasien yang dengan CC dapat berovulasi tetapi endometrium tipis. Mengingat efek yang sedikit merugikan dan harga rendah, L digunakan sebagai pengganti gonadotropin pada pasien yang resisten-CC. L diekskresi sangat cepat dan tak ada fetotoksisitas. ${ }^{17}$ Pada penelitian Hajishafiha M dkk., pada 100 perempuan PCOS yang gagal ovulasi dengan CC selama 6 siklus dilanjutkan dengan L selama 4 siklus juga gagal ovulasi, maka diberikan kombinasi $\mathrm{CC}+\mathrm{L}$, dengan jumlah 257 siklus, didapatkan kehamilan 42, yang terdiri kehamilan tunggal 37 (10 terjadi abortus), kehamilan kembar 5 (semua sampai aterm). Sehingga diusulkan terapi kombinasi ini dapat digunakan sebelum memberikan terapi agresif yang mungkin mempunyai komplikasi yang berat atau tindakan operatif. Kombinasi ini juga dapat dipergunakan sebagai terapi lini pertama untuk induksi ovulasi pada PCOS berat untuk menghemat waktu dan uang. ${ }^{17}$

Casper RF dkk menyimpulkan dari 2 penelitian multisenter RCT yang luas pada klinik National Institute of Child Health and Human Development (NICHD) Reproductive Medicine Network, membandingkan CC dan L, 750 pasien dengan PCOS, dari 11 klinik sekitar US, disimpulkan bahwa L tampaknya minimal sama efektifnya dengan CC untuk induksi ovulasi dan mendapatkan kelahiran hidup, dengan beberapa keuntungan dibandingkan dengan CC; juga mendapatkan bukti yang kuat efikasi dan keselamatan AI dibanding CC untuk terapi infertilitas. Half-life L yang pendek dan cepat bersih/hilang, akan mencegah akumulasi obat dari ulangan siklus, mengurangi kejadian kelainan bayi lahir. ${ }^{18}$

Pada penelitian manusia telah terbukti bahwa $\mathrm{L}$ tidak menunjukkan adanya peningkatan risiko anomali fetal atau keluaran kehamilan yang merugikan. ${ }^{1}$

Dosis A 1mg perhari setara dengan L 2,5 mg perhari. Dosis tunggal L hasilnya sebanding dengan regimen dosis 5 hari dalam hal stimulasi ovarium pada perempuan infertil. Tredway D dkk, 2011 meneliti A dosis tunggal 5, 10, 20, dan $30 \mathrm{mg}$ dibanding dengan CC $50 \mathrm{mg}$ perhari untuk 5 hari, dengan hasil A dosis tunggal tidak se-efektif dibanding CC $50 \mathrm{mg}$ perhari untuk 5 hari. Angka kehamilan klinik tidak bebeda antara A $5 \mathrm{mg}$ dengan CC 50 mg/hari. Dosis tunggal A 5, 10, dan $20 \mathrm{mg}$ ditoleransi dengan baik, tidak didapati kehamilan multipel atau OHSS pada A. ${ }^{19}$

Tinjauan Cochrane oleh Franik S dkk, 2014, terhadap terapi AI (dipakai L)pada perempuan subfertil dengan PCOS : ternyata L lebih unggul dari CC untuk terapi perempuan subfertil PCOS yang belum pernah menggunakan terapi induksi ovulasi sebelumnya atau resisten-CC. Nampak tidak ada perbedaan efektivitas antara L dan laparoskopi drilling ovarium, walaupun hanya ada dua penelitian yang relevan. OHSS 
TABEL 1

Letrozoledibanding clomiphene citrate, kelahiran hidup, OHSS, kehamilan klinik $^{20}$

Summary of findings.

Population : Subfertile women with polycyctic ovary syndrome.

Comparison : Aromatase inhibitor (letrozole) compared with clomiphene citrate, with or without adjuncts in both arms, followed by timed intercourse.

Illustrative comparative risks ${ }^{\mathrm{a}}$ (95\% Cl)

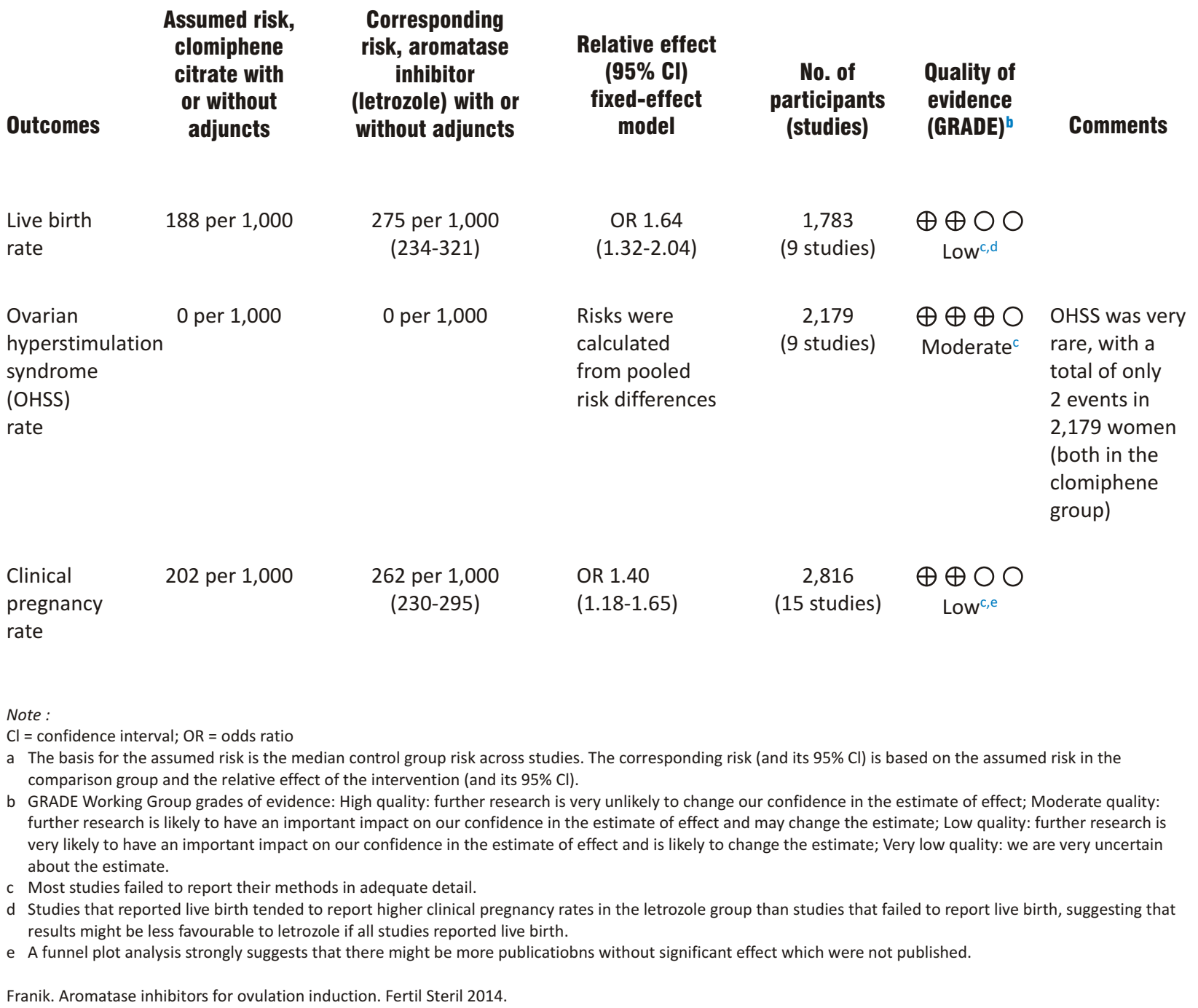

kejadiannya sangat jarang dan tidak didapatkan kejadian tersebut dari sebagian besar penelitian. Perlu diingat bahwa kesimpulan ini harus hati-hati oleh karena kualitas kejadian yang dievaluasi (lahir hidup) adalah rendah. $^{20}$

\section{SIMPULAN}

Clomiphene Citrate adalah anti estrogen, Selective Estrogen Receptor Modulator, telah dipakai lebih dari 40-45 tahun. Pengaruh positif berupa keberhasilan ovulasi, dan pengaruh negatif berupa penipisan endometrium dan endoserviks. Angka ovulasi $60-85 \%$, angka kehamilan 
30-40\%; ada yang mendapatkan angka berturut-turut untuk ovulasi, kehamilan, lahir hidup adalah 49\%, 30\%, $23 \%$; rendahnya angka tersebut oleh karena penipisan endometrium dan meningkatnya sekresi LH menyebabkan luteinisasi prematur.

Resisten-CC adalah tetap anovulasi setelah menerima terapi CC $150 \mathrm{mg} /$ hari atau $200 \mathrm{mg} /$ hari untuk 5 hari, atau terapi CC standar (100 mg perhari untuk 5 hari selama 2-3 siklus). Angka kejadian resisten-CC adalah 15-20\%.Terapi alternatif untuk pasien resisten-CC banyak cara, di antaranya adalah memperpanjang lama pemberian $\mathrm{CC}$, diganti dengan aromatase inhibitor, tamoxifen, gonadotropins, ovarian drilling, dan invitro fertilization.

Aromatase inhibitor generasi ke-3 adalah Exemestane, Letrozole, dan Anastrozole, untuk terapi kanker payudara. L dan A telah banyak dipakai untuk induksi ovulasi. Induksi ovulasi dengan A $1 \mathrm{mg} /$ hari atau L 2,5 mg/hari selama 5 hari mempunyai keberhasilan yang sama dengan L. Pemberian L pada hari ke 3-7 menstruasi, menghambat aromatase di ovarium, terjadi akumulasi androgen intraovarium, sekresi E2 ovarium tertekan akan mengurangi umpan balik negatifestrogen pada hipothalamus dan pituitari. Terjadi peningkatan sekresi FSH dari pituitari anterior. Akumulasi androgen didalam folikel akan meningkatkan sensitivitas folikuler terhadap FSH, folikulogenesis yang terjadi menghasilkan folikel multipel. Akhir fase folikuler, pengaruh AI menurun, dan kadar E2 meningkat, terjadi pertumbuhan folikel. Oleh karena AI tidak berpengaruh pada pusat reseptor esterogen, kadar E2 yang meningkat berakibat umpan balik negatif normal pada sekresi FSH, folikel yang lebih kecil dari folikel dominan mengalami atresi, dengan hasil ovulasi monofolikuler.

L tidak mempunyai efek samping anti estrogenik perifer, dan half-life 48 jam, obat hilang dari tubuh 10 hari setelah obat terakhir, sehingga jarang terjadi simtom antiestrogenik. Efek samping utama adalah hotflash, nyeri otot ringan, dan keluhan gastrointestinal. Terapi A dan L tidak didapati OHSS maupun kehamilan multipel. Tidak mempunyai pengaruh negatif terhadap endometrium maupun mukus serviks. Angka kehamilan dan angka kelahiran hidup cukup tinggi. Dengan L didapatkan untuk angka ovulasi 70-85\%, kehamilan 20-27\%, tidak menunjukkan adanya peningkatan risiko anomali fetal atau keluaran kehamilan yang merugikan.

Hasil studi meta-analisis menunjukkan bahwa L lebih unggul dari CC untuk terapi PCOS yang belum pernah menggunakan induksi ovulasi sebelumnya atau resisten-CC. Tidak ada beda efektivitas dengan laparoskopi drilling ovarium.

\section{DAFTAR PUSTAKA}

1. Nafee T, Metwally M. Induction of ovulation. Obstetric, Gynecology and reproductive medicine. 2004;24:117-21

2. Hashim HA, Shokeir T, Badawy A. Letrozole versus combined metformin and clomiphene citrate for ovulation induction in clomiphene-resistant women with polycystic ovary syndrome:a randomized contolled trial. Fertil Steril 2010; 94:1405-9

3. Wallace KL, Johnson V, Sopelak V, Hines R. Clomiphene citrate versus letrozole: molecular analysis of the endometrium in women with polycystic ovary syndrome. Feertil Steril. 2011; 96: 1051-6.

4. Badawy A, Aal IA, Abulatta M. Clomiphene citrate of anastrozole for ovulation induction in women with polycystic ovary syndrome? A prospective controlled trial. Fertil Steril. 2009; 92: 860-3.

5. Kamath MS, Aleyamma TK, Chandy A, George K. Aromatase inhibitor in women with clomiphene citrate resistance: a randomized, double-blind, placebo-controlled trial. Fertil Steril 2010; 94: 2857-9.

6. Badawy A, Mosbah A, Shady M. Anastrozole or letrozole for ovulation induction in clomiphene-resistant women with polycystic ovarian syndrome: a prospective randomized trial. FertilSteril. 2008;89:1209-12.

7. The practice committee of the American society for reproductive medicine. Use of clomiphene citrate in infertile women: a committee opinion. Feertil Steril 2013;100:341-8.

8. Attar E, Bulun SE. Aromatase inhibitors: the next generation of therapeutics for endometriosis?. Fertil Steril. 2006;85: 1307-18.

9. Tredway DR, Schertz JC. Anastrozole versus clomiphene citrate: which is better for ovulation induction?. Fertil Steril 2011; 95: 1549-51.

10. Malloch L, Vlasak AR. An assessment of current clinical attitudes toward letrozole use in reproductive endocrinology practices. FertilSteril. 2013;100:1740-4.

11. Research Article. Enliven Archive. Available at: http://www.enlivenarchive. Accessed 2014.

12. Casper RF. Letrozole: ovulation or superovulation?. Fertil Steril. 2003; 80: 1335-7.

13. Kucherov A, Polotsky AJ, Menke M, Isaac B, McAvey B, Buyuk E, et all. Aromataase inhibitor causes increased amplitude, but not frequency of hypotalamic-pituitary output in normal women. Fertil Steril 2011; 95: 2063-6.

14. Rafaeey AE, Selem A, Badawy A. Combined coenzyme Q10 and clomiphene citrate for ovulation induction in clomiphenecitrate-resistant polycystic ovary syndrome. Reprod Biomed Online 2014;29: 119-124.

15. Montville CP, Khabbaz M, Aubuchon M, William DB, Thomas MA. Luteal Support with intravaginal progesterone increase clinical pregnancy rates in women with polycystic ovary syndrome using letrozole for ovulation induction. Fertil Steril 2010; 94: 678-83.

16. McKnight KK, Nodler JL, Cooper JJ, Chapman VR, Cliver SP, Bates GW. Body mass index-associated differences in response to ovulation induction with letrozole. Fertil Steril. 2011;96: 1206-8.

17. Hajishafiha $M$, Dehgan $M$, Kiarang N, Sadegh-Asahi N, Shayegh SN, Ghasemi-Rad M. Combined letrozole and clomiphene versus letrozole and clomiphene alone in infertile patients with polycytic ovary syndrome. Drug Desain, Develompent and Therapy. 2014; 8:1427-31.

18. Casper RF, Mitwally MFM. A historical perspective of aromatase inhibitors for ovulation induction. Fertil Steril. 2012;98:1352-5. 
19. Tredwy D, Schertz JC, Bock D, Hemsey G, Diamond MP. Anastrozole single-dose protocol in women with oligo or anovulatory infertility: results of a randomized phase II doseresponse study. FertilSteril. 2011;95: 1725-9e8.
20. Franik S, Kremer JAM, Nelen W, Farquhar C, Marjorybanks J. Aromatase inhibitor for subfertile women with polycystic ovary syndrome: summary of a Cochrane review. Fertil Steril. 2014:1-3. 